\title{
EP3 receptor isoforms are differentially expressed in subpopulations of primate granulosa cells and couple to unique G-proteins
}

\author{
Soon Ok Kim ${ }^{1}$ Brandy L Dozier ${ }^{1,+}$, Julie A Kerry ${ }^{2}$ and Diane M Duffy ${ }^{1}$ \\ Departments of ${ }^{1}$ Physiological Sciences and ${ }^{2}$ Microbiology and Molecular Cell Biology, Eastern Virginia \\ Medical School, PO Box 1980, Norfolk, Virginia 23501, USA \\ Correspondence should be addressed to D M Duffy; Email: duffydm@evms.edu
}

${ }^{\dagger} \mathrm{B}$ L Dozier is now at the Oregon National Primate Research Center, Beaverton, Oregon 97006, USA

\begin{abstract}
Prostaglandin $E_{2}\left(\mathrm{PGE}_{2}\right)$ produced within the ovarian follicle is necessary for ovulation. $\mathrm{PGE}_{2}$ is recognized by four distinct G-proteincoupled receptors. Among them, PTGER3 (also known as EP3) is unique in that mRNA splicing generates multiple isoforms. Each isoform has a distinct amino acid composition in the C-terminal region, which is involved in G-protein coupling. To determine whether monkey EP3 isoforms couple to different G-proteins, each EP3 isoform was expressed in Chinese hamster ovary cells, and intracellular signals were examined after stimulation with the EP3 agonist sulprostone. Stimulation of EP3 isoform 5 (EP3-5) reduced cAMP in a pertussis toxin (PTX)-sensitive manner, indicating involvement of Gai. Stimulation of EP3-9 increased cAMP, which was reduced by the general G-protein inhibitor GDP- $\beta$-S, and also increased intracellular calcium, which was reduced by PTX and GDP- $\beta$-S. So, EP3-9 likely couples to both Gas and a PTX-sensitive G-protein to regulate intracellular signals. Stimulation of EP3-14 increased cAMP, which was further increased by PTX, so EP3-14 likely regulates cAMP via multiple G-proteins. Granulosa cell expression of all EP3 isoforms increased in response to an ovulatory dose of human chorionic gonadotropin. Two EP3 isoforms were differentially expressed in functional subpopulations of granulosa cells. EP3-5 was low in granulosa cells at the follicle apex while EP3-9 was high in cumulus granulosa cells. Differential expression of EP3 isoforms may yield different intracellular responses to $\mathrm{PGE}_{2}$ in granulosa cell subpopulations, contributing to the different roles played by granulosa cell subpopulations in the process of ovulation.
\end{abstract}

Reproduction (2013) 146 625-635

\section{Introduction}

Prostaglandin (PG) production by the follicle is an essential prerequisite for successful ovulation (Murdoch et al. 1993). The midcycle surge of luteinizing hormone (LH) stimulates PG production by granulosa cells of ovulatory follicles, elevating follicular PGs to peak levels just before ovulation (Wong \& Richards 1991, Liu et al. 1997, Sirois \& Doré 1997, Duffy \& Stouffer 2001). Among PGs, $\mathrm{PGE}_{2}$ has been identified as the key PG that regulates essential ovulatory events including cumulus expansion, follicle rupture, and oocyte release. Inhibition of PG synthesis in vivo blocks ovulation, whereas co-treatment with $\mathrm{PGE}_{2}$ restores ovulation, supporting a crucial role for $\mathrm{PGE}_{2}$ in ovulation (Tsafriri et al. 1972, Duffy \& Stouffer 2002, Peters et al. 2004).

$\mathrm{PGE}_{2}$ exerts its actions by binding to four distinct G-protein-coupled receptors (GPCRs): PTGER1, PTGER2, PTGER3, and PTGER4 (also known as EP1, EP2, EP3, and EP4 respectively; Coleman et al. 1994, Narumiya et al. 1999). Among EP receptors, EP3 is unique in that alternative mRNA splicing gives rise to multiple isoforms. All EP3 isoforms share a common $\mathrm{N}$-terminal sequence, which includes hormone binding and membrane spanning regions. However, each isoform has a unique amino acid composition in the C-terminal region, which regulates intracellular location and plays a key role in G-protein coupling.

EP3 receptor-mediated intracellular signal transduction has been studied in many tissues. EP3 receptors have often been shown to inhibit cAMP generation by reducing adenylyl cyclase activity via Gai. EP3 receptors have also been shown to activate phospholipase $\mathrm{C}$ to release intracellular calcium via Gaq (Yang et al. 1994, Schmid et al. 1995). An unknown pertussis toxin (PTX)-sensitive G-protein can also link EP3 to regulation of intracellular calcium (Tomić et al. 2002). Less frequently, EP3 has been shown to increase adenylyl cyclase activity by coupling to Gas or to activate the small G-protein Rho by coupling to $\mathrm{G}_{12 / 13}$ (An et al. 1994, Tamma et al. 2003). 
EP3 receptors have been implicated in ovulatory events in large animal species, including primates. EP3 receptors are expressed in mural and cumulus granulosa cells of ovarian follicles, with increased expression after the ovulatory gonadotropin surge (Tsai et al. 1996, Calder et al. 2001, Markosyan et al. 2006, Bridges \& Fortune 2007, Harris et al. 2011). High EP3 expression in bovine cumulus cells correlates with improved quality of the oocyte and the surrounding cumulus (Calder et al. 2001). A role for EP3 receptors to promote luteinization, an essential event in ovulatory cascade of large animal species, has also been suggested, and EP3 mRNA is highly expressed in bovine and monkey luteal cells (Tsai et al. 1996, Bogan et al. 2008a, 2008b). In monkey granulosa cells, EP3 receptors regulate both tissue-type plasminogen activator (PLAT) and plasminogen activator inhibitor type 1 (SERPINE1), key mediators of proteolysis associated with follicle rupture (Markosyan \& Duffy 2009). While mice lacking EP3 expression exhibit no gross reproductive abnormalities (Fleming et al. 1998), EP3 receptors have been implicated in essential ovulatory events in large animal species, which ovulate a single follicle.

The objectives of this study were to i) determine which EP3 receptor isoforms are expressed in monkey granulosa cells during the ovulatory interval, ii) identify the intracellular signals regulated by each monkey EP3 isoform, and iii) examine the distribution of EP3 isoforms among subpopulations of granulosa cells within the primate ovulatory follicle. Differential expression of EP3 isoforms may allow different roles for each granulosa cell subpopulations in the overall process of ovulation in response to ovulatory concentrations of $\mathrm{PGE}_{2}$.

\section{Materials and methods}

\section{Animal protocols}

Granulosa cells and whole ovaries were obtained from adult female cynomolgus macaques (Macaca fascicularis, aged 4-10 years, 2.5-4.0 kg) at Eastern Virginia Medical School (Norfolk, VA, USA). All animal protocols and experiments were approved by the Eastern Virginia Medical School Animal Care and Use Committee and were conducted in accordance with the National Institutes of Health's Guide for the Care and Use of Laboratory Animals. Animal husbandry and sample collections were performed as described previously (Duffy et al. 2005a). Briefly, adult females were checked regularly for menstruation, and the first day of menstruation was designated as day 1 of the menstrual cycle. Blood samples were obtained following ketamine chemical restraint $(5-10 \mathrm{mg} / \mathrm{kg}$ body weight; Henry Schein, Port Washington, NY, USA) by femoral venipuncture, and serum was stored at $-20{ }^{\circ} \mathrm{C}$. Aseptic surgeries were performed in a dedicated surgical suite under isofluorane anesthesia using midline laparotomy or laparoscopic procedures.

A controlled ovarian stimulation model, developed for the collection of multiple oocytes for IVF, was used to obtain monkey granulosa cells and whole ovaries (Vandevoort et al. 1989). Beginning within 3 days of initiation of menstruation, recombinant human follicle-stimulating hormone $(\mathrm{r}-\mathrm{hFSH}$; 90 IU daily; Merck \& Co.) was administered for 6-8 days, followed by daily administration of $90 \mathrm{IU}$ r-hFSH plus $60 \mathrm{IU}$ r-hLH (Serono Reproductive Biology Institute, Rockland, MA, USA) for 2-3 days to stimulate the growth of multiple preovulatory follicles. The gonadotropin-releasing hormone antagonist Ganirelix acetate $(30 \mu \mathrm{g} / \mathrm{kg}$ per day; Merck \& Co.) or Antide $(0.5 \mathrm{mg} / \mathrm{kg}$ per day; Serono) was also administered daily to prevent an endogenous ovulatory LH surge. Adequate follicular development was monitored by ultrasonography and serum estradiol and progesterone levels using the Immulite 1000 immunoassay system (Siemens Medical Diagnostics Solutions, Flanders, NJ, USA). Follicular aspiration was performed before $(0 \mathrm{~h}), 12,24$, and $36 \mathrm{~h}$ after administration of $1000 \mathrm{IU}$ recombinant human chorionic gonadotropin (hCG; Serono) using a 22 gauge syringe to collect the aspirates of all follicles with a diameter of more than $4 \mathrm{~mm}$. Whole ovaries were also removed from additional monkeys undergoing controlled ovarian stimulation before and after hCG administration. These times were selected to span the monkey ovulatory interval. Ovulation typically occurs about $40 \mathrm{~h}$ after the endogenous LH surge in natural menstrual cycles (Weick et al. 1973). Consistent with our previous studies, ovulation was not observed before or at $36 \mathrm{~h}$ following hCG administration.

To obtain granulosa cells, follicular aspirates were centrifuged at $250 \mathrm{~g}$. Pelleted cells were resuspended, and after oocyte removal, a granulosa cell-enriched population of the remaining cells was obtained by Percoll gradient centrifugation (Chaffin et al. 1999). Viability of granulosa cell-enriched preparations was assessed by trypan blue (Sigma-Aldrich) exclusion and averaged 85\%.

\section{$3^{\prime}$-RACE and cloning}

Total RNA was isolated from monkey granulosa cells using TRIzol reagent (Invitrogen) according to the manufacturer's instructions with the addition of $25 \mu \mathrm{g} / \mathrm{ml}$ glycogen (Roche Diagnostics) at the RNA precipitation step. The full-length cDNA sequences of EP3 receptor variable regions were obtained using the RACE Kit (Roche). Briefly, total RNA obtained from granulosa cells was reverse transcribed using an oligo-dT anchor primer. cDNA was amplified by PCR with a PCR anchor and a gene-specific forward primer for the EP3 common region (5'-TTATCAGGAGCGGAGAC-3') previously designed in our laboratory (Markosyan et al. 2006). To obtain the full-length cDNA sequence of the EP3 common region, conventional PCR was performed using a forward primer $5^{\prime}$-GTAAACGCCGACCTCC- $3^{\prime}$ and a reverse primer $5^{\prime}$-GCAAAACTTTCGAAGAAGG-3'. The RACE fragments of the EP3 variable regions and the EP3 common region cDNA were gel purified using the Qiaquick gel extraction kit (Qiagen) and cloned using the StrataClone PCR Cloning Kit (Agilent Technologies, Wilmington, DE, USA) for amplification and sequencing. For the StrataClone PCR cloning system, forward primer 5'-CGGGACTAGCTCTTCG-3' and reverse primer $5^{\prime}$-TTATCAGGAGCGGAGAC-3' for variable regions and forward primer $5^{\prime}$-GCTCTCTGGACGCTAT-3' and reverse primer 
5'-GCAAAACTTTCGAAGAAGG-3' for EP3 common region were used. In order to express each full-length EP3 receptor isoform, the EP3 common region and a single variable region were then ligated and subcloned into eukaryotic expression vectors. pcDNA3.1 (Invitrogen) has a powerful cytomegalovirus immediate early promoter and is widely used for mammalian transient expression. pSI (Promega) was also used as it has a weak simian virus 40 (SV40) promoter and results in reduced levels of expression of the inserted genes (Garmory et al. 2003). The correct open-reading frame and amino acid sequence for each EP3 receptor C-terminal region was determined using EMBOSS Transeq (EMBL-EBI, Hinxton, Cambridgeshire, UK).

\section{Cell line culture and transfection}

Chinese hamster ovary (CHO) cells (ATCC, Manassas, VA, USA) were cultured in F-12K (Kaighn's Modification of Ham's F-12) medium (ATCC) supplemented with $10 \%$ fetal bovine serum (Bench Mark, Millwood, WV, USA) and 1\% antibioticantimycotic solution (Gibco) containing $10000 \mu \mathrm{g} / \mathrm{ml}$ streptomycin, 10000 units $/ \mathrm{ml}$ penicillin, and $25 \mu \mathrm{g} / \mathrm{ml}$ amphotericin B. Cells were transfected by plasmid DNA expressing green fluorescent protein (GFP) or each EP3 receptor isoform using Lipofectamine 2000 (Invitrogen) according to the manufacturer's instructions. Briefly, 1 day before transfection, cells were seeded in $\mathrm{F}-12 \mathrm{~K}$ with no antibiotics and incubated until $\sim 80 \%$ confluency. Cells were washed with PBS and cultured with the transfection complexes containing plasmid DNA in fresh medium with no supplements. Approximately $48 \mathrm{~h}$ after transfection, GFP expression was examined for transfection efficiency (80-90\%), and cells were then used for each experiment. Mock-transfected cells supplemented with transfecting reagent alone served as a control. Cells transfected with empty vector, which was not carrying any EP3 receptor isoform, also served as a control.

Preliminary experiments (not shown) confirmed that $\mathrm{CHO}$ cells do not express endogenous EP3 receptors. EP3 receptors were not detected in mock-transfected or empty vectortransfected $\mathrm{CHO}$ cells by immunocytochemistry using an EP3 antibody, following methods previously described by this laboratory (Markosyan et al. 2006). Mock-transfected and empty vector-transfected $\mathrm{CHO}$ cells did not respond to $\mathrm{PGE}_{2}$ or sulprostone with alterations in intracellular calcium or cAMP.

\section{Immunofluorescence detection}

The hemagglutinin (HA) tag was inserted before the EP3 common region of each isoform using the QuikChange site-directed mutagenesis kit (Stratagene, La Jolla, CA, USA). Approximately $48 \mathrm{~h}$ after transfection, $\mathrm{CHO}$ cells were fixed with 10\% buffered formalin (Fisher Diagnostics, Middletown, VA, USA) and blocked with $5 \%$ non-immune goat serum (Vector Labs, Burlingame, CA, USA) in PBS containing 0.1\% Triton X (PBS-Triton) for $1 \mathrm{~h}$ at room temperature. Cells were incubated overnight with an anti-HA tag antibody (1:1000; Covance, Berkeley, CA, USA) followed by an Alexa Fluor 488-conjugated anti-mouse secondary antibody $(400 \mu \mathrm{g} / \mathrm{ml}$; Molecular Probes, Eugene, OR, USA). Finally, cells were washed with PBS and mounted in Vectashield medium containing propidium iodide (Vector Labs) for nuclei staining. Images were obtained using a Zeiss LSM 510 confocal microscope (Carl Zeiss, Inc., Thornwood, NY, USA) at $488 \mathrm{~nm}$ (green) for EP3 receptor isoforms and $543 \mathrm{~nm}$ (red) for nuclei. Incubation with no primary antibody was used to determine background levels of fluorescence.

\section{cAMP concentration}

Transfected $\mathrm{CHO}$ cells were treated with the EP3 agonist sulprostone ( $1 \mu \mathrm{M}$; Cayman Chemical, Ann Arbor, MI, USA) or vehicle $(0.01 \%$ DMSO) for $4 \mathrm{~h}$. To block G-protein activity, some cells were preincubated with PTX $(100 \mathrm{ng} / \mathrm{ml}$; Sigma; $20 \mathrm{~h}$ ) or GDP- $\beta$-S (100 $\mu \mathrm{M}$; Sigma; $30 \mathrm{~min})$ prior to treatment with sulprostone or vehicle. PTX is primarily known as a Gai inhibitor but also inhibits one or more unidentified G-proteins that regulate intracellular calcium. GDP- $\beta-S$ is a general G-protein inhibitor. Media were then assayed for cAMP levels by EIA (Cayman Chemical) following manufacturer's instructions including cAMP acetylation for maximum sensitivity. All samples were assayed in duplicate. cAMP levels were normalized to cell number of each well. Levels of cAMP in treated culture wells are expressed relative to cAMP in vehicle-only (control) wells. A single batch of transfected $\mathrm{CHO}$ cells was used for each independent experiment, providing data suitable for repeated measures analysis.

\section{Calcium measurements}

Assessments of intracellular calcium were performed using the Fluo-4 NW Calcium Assay Kit (Molecular Probes). Approximately $48 \mathrm{~h}$ after transfection, media were replaced with Fluo-4 NW dye mix and $2.5 \mathrm{mM}$ probenecid diluted in Hanks' balanced salt solution with $20 \mathrm{mM}$ HEPES. Cells were incubated at $37^{\circ} \mathrm{C}$ for $30 \mathrm{~min}$ and then at room temperature for an additional $30 \mathrm{~min}$. After determination of basal fluorescence before treatment $(0 \mathrm{~s})$, cells were stimulated with sulprostone $(1 \mu \mathrm{M})$ or vehicle $(0.01 \% \mathrm{DMSO})$. Some cells were preincubated with PTX $(100 \mathrm{ng} / \mathrm{ml} ; 20 \mathrm{~h})$ or GDP- $\beta$-S (100 $\mu \mathrm{M} ; 30 \mathrm{~min}$ ) before sulprostone administration. Fluorescence was measured every $20 \mathrm{~s}$ for $2 \mathrm{~min}$ in a SpectraMax multimode microplate reader (Molecular Devices, Sunnyvale, CA, USA) with excitation at $494 \mathrm{~nm}$ and emission at $516 \mathrm{~nm}$. Finally, cells were exposed to the calcium ionophore A23187 (10 $\mu$ M; Calbiochem, San Diego, CA, USA) to confirm cell responsiveness. Fluorescence measured after sulprostone or A23187 treatment is expressed relative to basal level, where basal level is set equal to 1.0.

\section{Real-time PCR}

Total RNA isolated from monkey granulosa cells was reverse transcribed as described previously (Duffy et al. 2005b). Granulosa cell mRNA was assessed for each EP3 receptor (PTGER3) isoform and ACTB by real-time PCR (RT-PCR) using a Roche LightCycler (Roche). PCR was performed using the FastStart DNA Master SYBR Green I kit (Roche) following the manufacturer's instructions. Primers specific for each 
cynomolgus macaque EP3 receptor (PTGER3) isoform and $A C T B$ were designed using LightCycler Probe Design Software (Roche) based on the human or monkey sequences (Table 1). All primers span an intron to prevent undetected amplification of genomic DNA. A standard curve was generated for each primer set over at least five log dilutions using monkey cDNA of known copy number. For each sample, the copy numbers for each EP3 (PTGER3) isoform and ACTB mRNA were determined in independent assays. No amplification was observed when monkey cDNA was omitted. All data are expressed as the ratio of mRNA of interest to $A C T B$ mRNA for each sample.

\section{Granulosa cell subpopulations}

Cumulus-oocyte complexes were mechanically removed from follicular aspirates. The remaining cells (mural granulosa cells) were enriched by Percoll gradient centrifugation as described earlier. Cumulus cells were removed from oocytes using stripper tips (Mid-Atlantic Diagnostics, Mt Laurel, NJ, USA). Each subpopulation of granulosa cells was frozen separately in liquid nitrogen and stored at $-80{ }^{\circ} \mathrm{C}$ for isolation of total RNA.

To obtain apex and non-apex granulosa cells of monkey ovarian follicles, whole stimulated monkey ovaries obtained before $(0 \mathrm{~h})$ and $36 \mathrm{~h}$ after hCG administration were bisected such that at least two follicles $>4 \mathrm{~mm}$ in diameter were present on each piece. The ovarian pieces were covered with O.C.T. compound (Sakura, Tokyo, Japan), frozen in liquid propane, and stored at $-80{ }^{\circ} \mathrm{C}$ prior to sectioning at $10 \mu \mathrm{m}$.

Laser capture microscopy (LCM) was used to obtain apex and non-apex granulosa cells as described previously (Harris et al. 2011). Briefly, monkey ovarian tissue sections were dehydrated as described by Arcturus HistoGene Frozen Section Staining Kit (Applied Biosystems) with the addition of a 2.5-min incubation with Nuclear Fast Red counterstain following distilled water incubations (Vector Labs). The granulosa cells adjacent to the thinnest area of the ovarian stroma were identified as apex mural granulosa cells while granulosa cells opposite the apex were identified as non-apex mural granulosa cells. These subpopulations of granulosa cells were captured onto CapSure Macro LCM caps (Molecular Devices) using an Arcturus AutoPix 100e LCM system (Mountain View, CA, USA).
Total RNA was isolated from mural and cumulus granulosa cells using the TRIzol method described earlier. For laser capture microdissection samples, the caps for apex and non-apex granulosa cells were dissolved in $200 \mu$ l TRIzol (Invitrogen) by inverting every $30 \mathrm{~min}$ for $1 \mathrm{~h}$, and total RNA was obtained using the standard protocol for TRIzol. For all granulosa cell subpopulations, RNA amplification was conducted using the first amplification cycle in the Small Sample Labeling Protocol Version VII (small sample protocol, version II; Affymetrix, Santa Clara, CA, USA). This amplification was followed by RT of the T7 amplified RNA using M-MLV reverse transcriptase (Invitrogen). cDNA was then purified using Qiaquik PCR purification kit (Qiagen). mRNA levels for EP3 receptor (PTGER3) isoforms and $A C T B$ in each subpopulation were assessed by RT-PCR as described earlier.

\section{Statistical analysis}

All data sets were assessed for heterogeneity of variance by Bartlett's test. Data were $\log _{10}$ transformed when Bartlett's test yielded $P<0.05$; log-transformed data were subjected to Bartlett's test to confirm that $P>0.05$. All data sets were assessed by t-test or ANOVA followed by Duncan's post-hoc test using StatPak Software, version 4.12 (Northwest Analytical, Portland, OR, USA). Significance was assumed at $P<0.05$. Data are presented as mean \pm S.E.M.

\section{Results}

\section{Identification of EP3 receptor isoforms expressed by monkey granulosa cells}

After cDNA amplification and sequencing of the C-terminal region of each monkey EP3 isoform, the cDNA sequences were compared with human and available monkey sequences. Five EP3 isoforms were detected in monkey granulosa cells obtained throughout the ovulatory interval (Table 2). Monkey isoforms with high sequence homology to human EP3 isoforms are identified using previously reported nomenclature (Bilson et al. 2004). Monkey isoforms without highsequence homology to previously reported isoforms are identified here as isoforms EP3-13 and EP3-14.

Table 1 Primer sequences for monkey EP3 receptor isoforms and ACTB.

\begin{tabular}{|c|c|c|c|c|c|}
\hline Target & Sequence $\left(5^{\prime}-3^{\prime}\right)$ & $\begin{array}{l}\text { Amplified cDNA } \\
\text { (bp) }\end{array}$ & $\begin{array}{c}\text { Published human } \\
\text { sequence }\end{array}$ & $\begin{array}{c}\text { Identity between } \\
\text { monkey and human } \\
\text { sequence }(\%)\end{array}$ & $\begin{array}{l}\text { Monkey amplified fragment } \\
\text { accession no. }\end{array}$ \\
\hline EP3-5 & F: CCATTCAGCTCATGGGGA & 388 & NM_198715 & 98.6 & KC154006 \\
\hline EP3-7 & $\begin{array}{l}\text { R: ACAGTAAGGTTTAGCATATTTG } \\
\text { F: TGGTCTCCGCTACTGA } \\
\text { R: ACAATTCCTCCTGGCAA }\end{array}$ & 204 & NM_198717 & 97 & KC154007 \\
\hline EP3-9 & $\begin{array}{l}\text { F: CAACCTTGATGTGGAGT } \\
\text { R: CCGCTTCGGTTAAGATT }\end{array}$ & 382 & NM_198719 & 95 & KC154008 \\
\hline EP3-13 & $\begin{array}{l}\text { F: TTTGGGTTGCTTTCACCT } \\
\text { R: AGAGAGTCATGGAGCATC }\end{array}$ & 201 & & & KC154010 \\
\hline EP3-14 & $\begin{array}{l}\text { F: CCCACAACAACCTTGTATG } \\
\text { R: AGTGGCCCCAAATGTTA }\end{array}$ & 267 & & & KC154011 \\
\hline$A C T B$ & $\begin{array}{l}\text { F: ATCCGCAAAGACCTGT } \\
\text { R: GTCCGCTAGAAGCAT }\end{array}$ & 270 & NM_001101 & 97.4 & AY765990 \\
\hline
\end{tabular}


Table 2 Carboxyl-terminal amino acid sequences for monkey EP3 receptor isoforms.

\begin{tabular}{ll}
\hline Isoform & \multicolumn{1}{c}{ C-terminal sequence } \\
\hline EP3-5 & WVYLLLRKILLRKSCQVANAVSSCSNDGQKGQPISLSNEIIQTEA \\
EP3-7 & WVYLLLRKILLRKFCQEEWGN \\
EP3-9 & WVYXLLRKIXLRKFCQIRYHTNNYASSSTSLPCQCSSTLMWSDHFQRQ \\
EP3-13 & WVYLLLRKILLRKFCQANIPLYLYTPFSVSIYMSMDIWVAFTSWLL \\
EP3-14 & WVYLLLRKILLRKFCQGDPLEDCGLPSTELKILCSSELTAWRSKQRKTGTA \\
\hline
\end{tabular}

${ }^{\mathrm{a} S t o p}$ codon.

\section{Expression of functional EP3 receptor isoform proteins}

$\mathrm{CHO}$ cells have been shown to express numerous G-proteins, so these cells are widely used to identify signal transduction pathways regulated by transfected GPCRs (An et al. 1994, Jin et al. 1997, Jakubík et al. 2006, Janíčková et al. 2013). CHO cells have been used as an in vitro cell model to study GPCRs and intracellular signaling that occurs in ovarian granulosa cells (Thiruppathi et al. 2001, Xing et al. 2006, Li et al. 2008). CHO cells were transiently transfected with a single HA-tagged EP3 isoform in the pcDNA3.1 vector in order to verify protein expression and determine the subcellular location of each EP3 receptor isoform (Fig. 1). In CHO cells expressing the EP3-5, EP3-9, and EP3-14 isoforms, fluorescence representing the EP3 receptor isoform was most prominent in the plasma membrane region. By contrast, fluorescence was present throughout $\mathrm{CHO}$ cells transfected with the EP3-7 and EP3-13 isoforms. These experiments were repeated using the $\mathrm{pSI}$ vector with the weaker promoter, and similar results were obtained (Fig. 1). Little or no staining was observed in $\mathrm{CHO}$ cells after mock transfection (not shown) or empty vector transfection (Fig. 1). Omission of primary antibody also resulted in little or no staining (Fig. 1, insets).
To identify G-proteins utilized by each monkey EP3 receptor isoform, $\mathrm{CHO}$ cells transfected with a single $E P 3$ isoform in the pcDNA3.1 vector were treated with the EP3 receptor-selective agonist sulprostone, and the intracellular signals cAMP and calcium were measured.

Sulprostone stimulation of $\mathrm{CHO}$ cells expressing EP3-5 slightly but significantly reduced cAMP levels when compared with control (Fig. 2A). cAMP levels were not altered by the Gai inhibitor PTX alone, but sulprostone stimulation after pretreatment with PTX increased cAMP levels compared with sulprostone alone. Similarly, the general G-protein inhibitor GDP- $\beta$-S alone did not alter CAMP, but treatment with sulprostone after GDP- $\beta-S$ increased cAMP above levels measured with sulprostone alone. Stimulation of EP3-5 by sulprostone did not alter intracellular calcium (Table 3). These findings are consistent with EP3-5 coupling to the Gai protein to regulate adenylyl cyclase and cAMP.

Sulprostone stimulation of $\mathrm{CHO}$ cells expressing EP3-9 increased cAMP levels when compared with control (Fig. 2B). GDP- $\beta$-S pretreatment reduced sulprostonestimulated cAMP levels but did not alter control cAMP levels. PTX pretreatment did not alter control- or sulprostone-stimulated cAMP. These data suggest that EP3-9 couples with Gas to increase adenylyl cyclase
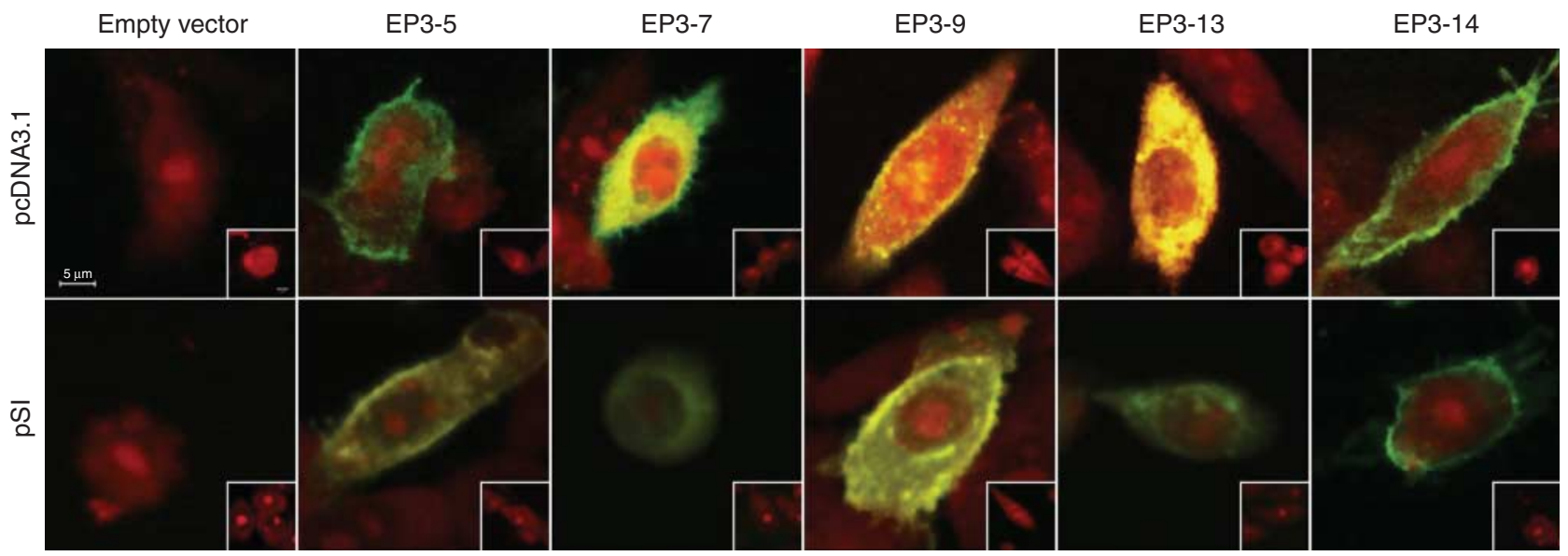

Figure 1 Subcellular localization of each EP3 receptor isoform. pcDNA3.1 (upper panels) and pSI (bottom panels) were used to determine the location of each monkey EP3 receptor isoform within CHO cells. Transient transfection with empty vector or vector containing a single EP3 receptor isoform with HA tag was performed. Cells were then fixed and stained with anti-HA tag antibody (green). Nuclei were stained with propidium iodide (red). No staining was observed when the primary antibody was omitted (insets). The results shown are representative of two independent experiments. All images are at the same magnification, with scale bar in upper left panel and inset (scale bars $=5 \mu \mathrm{m}$ ). 

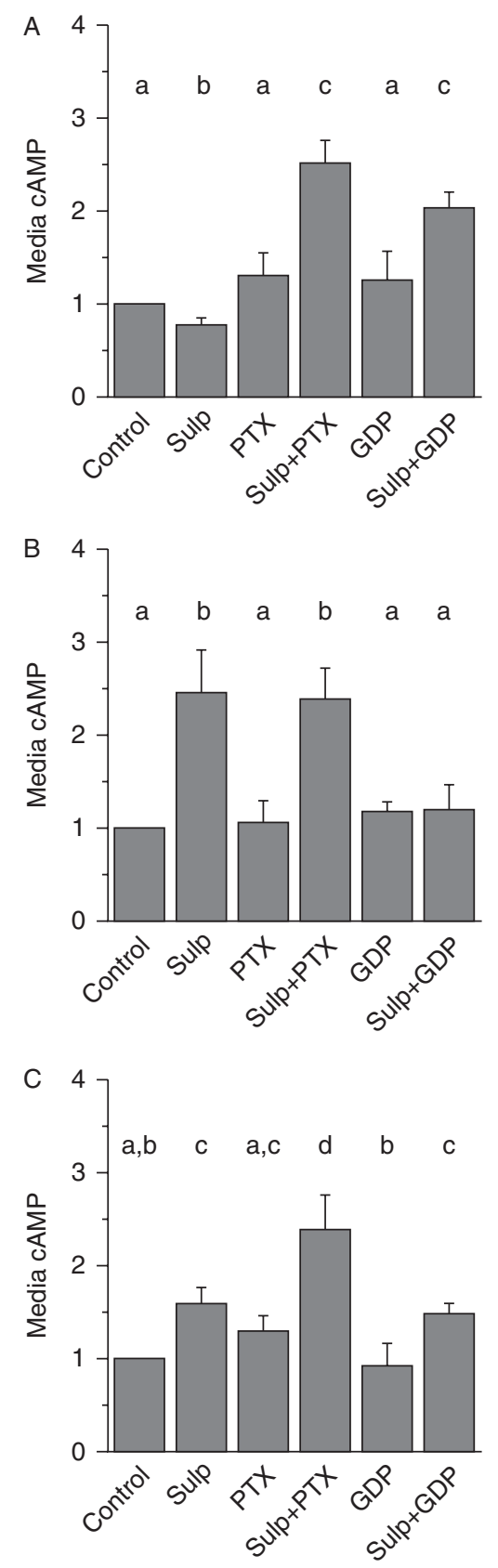

Figure $2 \mathrm{EP} 3$ receptor isoforms alter cAMP. CHO cells transiently transfected with EP3-5 (A), EP3-9 (B), or EP3-14 (C) were treated with $0.01 \%$ DMSO (control) or sulprostone (Sulp) for $4 \mathrm{~h}$. Cultured media were assessed for CAMP by EIA. Some cultures were pretreated with PTX or GDP- $\beta$-S (GDP) before addition of sulprostone. cAMP levels are presented relative to control, which is set equal to 1.0 for each independent experiment. Data are expressed as mean +S.E.M., $n=4-10$ independent experiments. Within each panel, data were assessed by ANOVA with one repeated measure, followed by Duncan's post-hoc test; groups with no common superscripts are different, $P<0.05$.

activity. Sulprostone treatment of $\mathrm{CHO}$ cells expressing EP3-9 also increased intracellular calcium (Fig. 3 and Table 3). This sulprostone-stimulated increase in intracellular calcium was blocked by pretreatment with either PTX or GDP- $\beta-S$, supporting the concept that a PTX-sensitive G-protein mediates the ability of EP3-9 to regulate calcium.

Sulprostone stimulation of $\mathrm{CHO}$ cells expressing EP3-14 increased cAMP levels compared with control (Fig. 2C). PTX alone did not alter cAMP levels, but PTX pretreatment further increased sulprostone-stimulated cAMP levels. GDP- $\beta$-S alone did not alter cAMP levels, and pretreatment with GDP- $\beta$-S did not alter sulprostonestimulated CAMP levels. Taken together, these observations suggest that more than one G-protein participates in the regulation of CAMP by EP3-14, which may include Gai as well as Gas. Sulprostone stimulation of $\mathrm{CHO}$ cells expressing EP3-14 did not alter intracellular calcium (Table 3). Sulprostone did not alter cAMP or intracellular calcium in $\mathrm{CHO}$ cells transfected with EP3-7 and EP3-13 (not shown).

\section{EP3 isoform expression in monkey granulosa cells}

To determine which EP3 receptor isoforms are regulated by gonadotropin during the ovulatory period, monkey granulosa cells obtained before $(0 \mathrm{~h})$ and 12,24 , and $36 \mathrm{~h}$ after hCG administration were assessed for each EP3 isoform mRNA by RT-PCR (Fig. 4). All isoforms showed low mRNA levels before (0 h) hCG. EP3-5 and EP3-7 isoforms increased $12 \mathrm{~h}$ after hCG treatment and maintained high levels through $36 \mathrm{~h}$ of hCG exposure. EP3-9 mRNA reached peak levels $12 \mathrm{~h}$ after hCG administration but fell to moderate levels $24-36 \mathrm{~h}$ after hCG. EP3-13 and EP3-14 expression showed the same pattern as EP3-5 and EP3-7, but these isoforms were expressed at levels tenfold lower than other EP3 isoforms.

To determine whether each functional EP3 receptor isoform has a unique temporal and spatial pattern of expression, granulosa cell subpopulations obtained before $(0 \mathrm{~h})$ and $36 \mathrm{~h}$ after hCG were assessed for expression of the functional EP3 isoforms: EP3-5, EP3-9, and EP3-14.

EP3-5 mRNA was significantly lower in apex granulosa cells compared with non-apex granulosa cells obtained $36 \mathrm{~h}$ after hCG (Fig. 5A). However, no differences were observed between apex and non-apex mural granulosa cell samples collected before hCG administration. Differences in EP3-5 mRNA levels between mural and cumulus granulosa cells were not observed at 0 or $36 \mathrm{~h}$ after hCG (not shown).

EP3-9 mRNA was higher in cumulus than in mural granulosa cells at $36 \mathrm{~h}$ after hCG while no differences between cumulus and mural granulosa cells were measured before $(0 \mathrm{~h})$ hCG (Fig. 5B). EP3-9 mRNA levels were not different between apex and non-apex granulosa cells at any time examined (not shown). Differences in EP3-14 mRNA levels were not observed between mural and cumulus or between apex and nonapex granulosa cells (not shown). 
Table 3 Regulation of intracellular calcium concentration via each monkey EP3 isoform.

\begin{tabular}{lccccr}
\hline $\begin{array}{l}\text { Time after } \\
\text { sulprostone treatment }\end{array}$ & $\mathbf{E P 3 - 5}$ & $\mathbf{E P 3 - 7}$ & $\mathbf{E P 3 - 9}$ & $\mathbf{E P 3 - 1 3}$ & EP3-14 \\
\hline $0 \mathrm{~s}$ & 1.00 & 1.00 & $1.00^{\mathrm{a}}$ & 1.00 & 1.00 \\
$40 \mathrm{~s}$ & $1.01 \pm 0.01$ & $1.07 \pm 0.08$ & $1.21 \pm 0.02^{\mathrm{b}}$ & $1.04 \pm 0.03$ & $1.06 \pm 0.03$ \\
lonophore & $1.22 \pm 0.02$ & $1.41 \pm 0.11$ & $1.76 \pm 0.16$ & $2.00 \pm 0.19$ & $1.97 \pm 0.20$ \\
\hline
\end{tabular}

All data are presented as mean \pm S.E.M., $n=3-7$ per group. ${ }^{\mathrm{a}, \mathrm{b}}$ Differences between before $(0 \mathrm{~s})$ and $40 \mathrm{~s}$ after treatment $(P<0.05)$ by two-tailed, paired $t$-test.

\section{Discussion}

This study is the first to examine EP3 receptor isoform expression in the ovulatory follicle. Five EP3 receptor isoform mRNAs were detected in the granulosa cells of monkey ovulatory follicles. The sequences of three isoforms (EP3-5, EP3-7, and EP3-9) were over 95\% identical to the sequences of the previously reported human isoforms (Bilson et al. 2004). Two other isoforms (EP3-13 and EP3-14) had previously unreported sequence insertions in the C-terminal domains or novel $3^{\prime}$ ends when compared with previously reported human $E P 3$ receptor isoforms. These unique sequences in the C-terminal domains may allow each EP3 isoform to localize to different areas within the cell and trigger different intracellular signaling pathways in response to ovulatory concentrations of $\mathrm{PGE}_{2}$.

The C-terminal region of the EP3 receptor participates in receptor localization within the cell. Monkey EP3 receptor isoforms EP3-5, EP3-9, and EP3-14 localized predominantly in the plasma membrane of $\mathrm{CHO}$ cells, whereas EP3-7 and EP3-13 were located throughout $\mathrm{CHO}$ cells. Use of the pcDNA3.1 and pSI vectors resulted in the same distribution of each EP3 isoform within $\mathrm{CHO}$ cells, suggesting that cellular location was not simply the result of massive overexpression. These data are consistent with other studies of EP3 receptor isoforms and support the concept that the C-terminal region controls, at least in part, the subcellular localization of these receptors (Hasegawa et al. 2000, Bilson et al. 2004). Studies of human EP3 receptor isoforms show that they differ in subcellular localization depending on the sequence of their C-terminal regions (Bilson et al. 2004). For example, the human EP3.I isoform (or hEP3-4) was localized to the cell surface. While EP3 isoforms denoted as EP3.III (or hEP3-7), EP3.IV (or hEP3-6), and EP3.f (or hEP3-CRAe) were found close to the plasma membrane, EP3.V (or hEP3CRAk) was localized to intracellular compartment(s). Upon stimulation with $\mathrm{PGE}_{2}$, EP3.I rapidly translocated to cytoplasmic vesicles; EP3 isoforms II (or hEP3-5), $\mathrm{V}, \mathrm{VI}$, and $\mathrm{f}$ showed less complete movement to cytoplasmic vesicles than did EP3.I. By contrast, the EP3.III and EP3.IV isoforms did not translocate to cytoplasmic vesicles after $\mathrm{PGE}_{2}$ treatment. A mouse EP3 isoform lacking the C-terminal region was observed exclusively in an intracellular compartment (Hasegawa et al. 2000), again supporting the concept that the
C-terminal region plays a pivotal role in directing the subcellular localization of EP3 receptor isoforms.

The amino acid composition in the C-terminal region of each EP3 receptor isoform is also crucial for interactions with G-proteins. To determine which G-proteins couple to each EP3 isoform, we assessed changes in cAMP and intracellular calcium, as these are the well-characterized second messengers close to G-proteins in signal transduction pathways. Stimulation of monkey EP3-5 with sulprostone decreased CAMP, likely via Gai. Elevated cAMP with sulprostone and PTX is similar to previous reports of elevated CAMP with agonist and PTX in other cells, but the specific G proteins involved remain to be identified (Israel \& Regan 2009, Talasila et al. 2009). Sulprostone stimulation of EP3-9 augmented cAMP concentrations, likely through Gas. Notably, the EP3-9 isoform may also couple to a PTXsensitive G-protein of the Gai subfamily (Tomić et al. 2002) to increase intracellular calcium. Stimulation of EP3-14 by sulprostone elevated CAMP, indicating that the EP3-14 isoform also activates the Gas protein. Pretreatment of CHO cells expressing EP3-14 with PTX increased

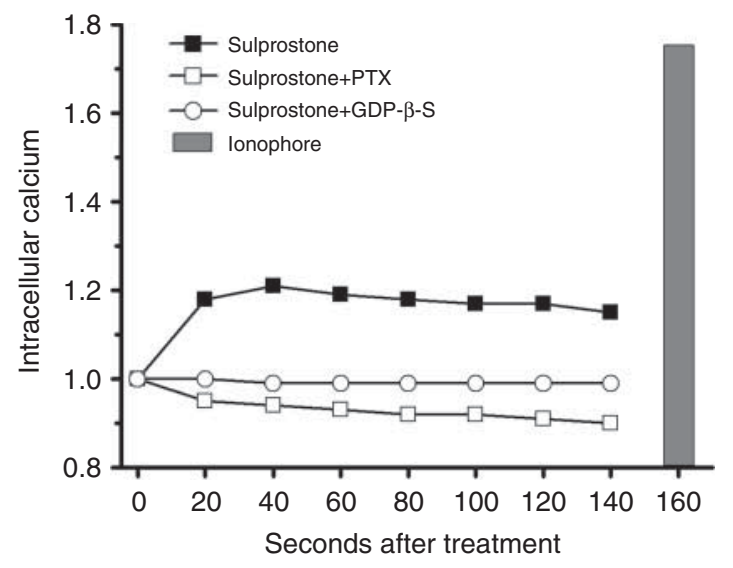

Figure 3 EP3-9 modulates intracellular calcium. CHO cells transiently transfected with the EP3-9 isoform were pretreated with no inhibitor (filled square), PTX (open square), or GDP- $\beta$-S (open circle); all cells were then incubated with the fluorescent calcium dye Fluo-4AM. Basal fluorescent emission was determined ( $0 \mathrm{~s})$. Sulprostone was added, and fluorescent emission of the same cells was measured every 20 s. Finally, cells were exposed to the calcium ionophore A23187 (gray bar) as a positive control. Fluorescence is expressed relative to basal levels, which is set equal to 1.0 for each independent experiment. The mean of seven independent experiments is shown. Statistics are shown in Table 3. 

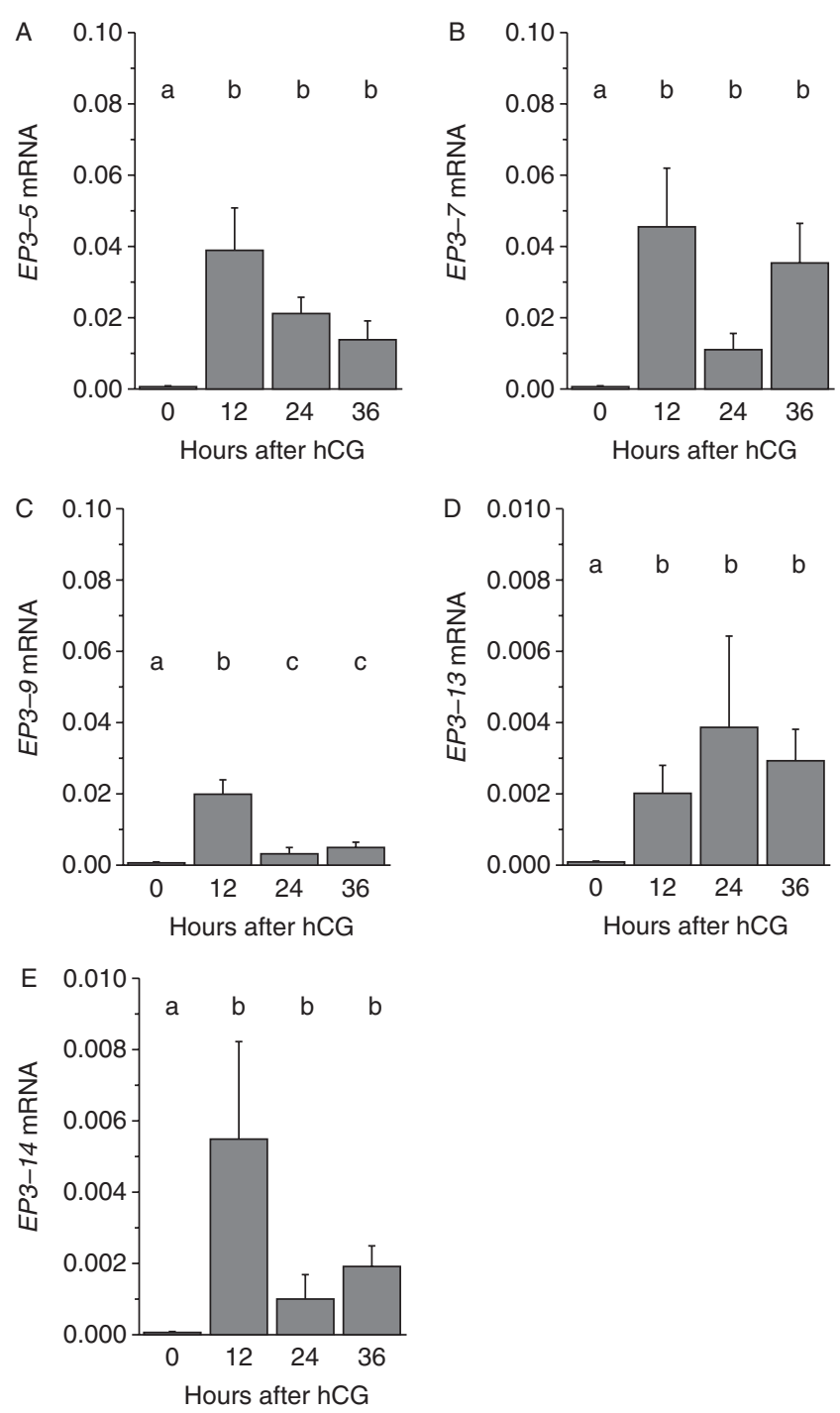

Figure $4 E P 3$ receptor isoform mRNA levels in monkey granulosa cells during the ovulatory interval. EP3-5 (A), EP3-7 (B), EP3-9 (C), EP3-13 (D), and EP3-14 (E) mRNA were quantified within monkey granulosa cells obtained before $(0 \mathrm{~h}), 12,24$, and $36 \mathrm{~h}$ after hCG administration. Each EP3 receptor isoform $m R N A$ was expressed relative to $A C T B$. Data are expressed as mean + S.E.M., $n=3-5$ monkeys per time point. With each panel, each EP3 isoform mRNA was assessed by ANOVA, followed by Duncan's post-hoc test. Groups with no common superscripts are different, $P<0.05$.

sulprostone-stimulated cAMP, but pretreatment with GDP- $\beta$-S did not alter cAMP level compared with sulprostone treatment alone, indicating a complex role for EP3-14 in regulating cAMP levels. Our data confirm and extend the findings of studies of EP3 receptor isoforms in that differences in amino acid composition of the C-terminal region result in coupling to different G-protein. In humans, EP3.II and EP3.IV isoforms increased cAMP via Gas while EP3.I and EP3.II activated Gaq (Kotani et al. 1995). In mice, while EP3 $\alpha$ and EP3 $\beta$ coupled to $\mathrm{G} \alpha \mathrm{i}$ and resulted in reduction of cAMP, EP3 $\gamma$ coupled to both Gai and Gas (Irie et al. 1993, Sugimoto et al. 1993). Pretreatment of the mouse EP3 receptor isoform EP3 $\alpha$ with PTX blocked a $\mathrm{PGE}_{2}$-induced increase in intracellular calcium, indicating that a PTX-sensitive $\mathrm{G}$-protein was involved in the $\mathrm{PGE}_{2}$-induced changes in intracellular calcium in this species as well (Irie et al. 1994). Previous studies by our laboratory demonstrated that EP3 stimulation of the total aspirated granulosa cell population obtained from monkey follicle aspirates just before ovulation increased CAMP and did not alter intracellular calcium (Markosyan et al. 2006). Total aspirated granulosa cells contain relatively few cumulus granulosa cells, and EP3-9 is expressed primarily in cumulus cells, perhaps explaining why sulprostone did not increase intracelluar calcium in our previous study. In summary, monkey granulosa cells likely express primarily EP3-9 and/or EP3-14 proteins in response to the ovulatory dose of gonadotropin as these isoforms are capable of increasing cellular cAMP. However, these and other EP3 isoforms may be highly expressed in specific regions of the follicle and play locally important roles in the ovulatory response to $\mathrm{PGE}_{2}$.
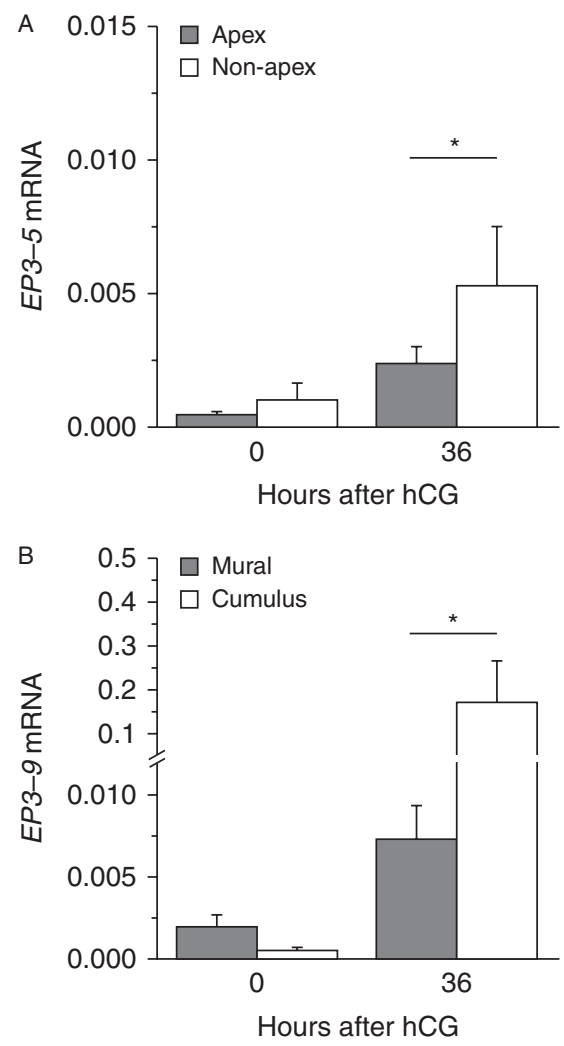

Figure 5 Expression of functional $E P 3$ receptor isoforms in monkey granulosa cell subpopulations. EP3-5 (A) and EP3-9 (B) mRNA were quantified within apex, non-apex, mural, and cumulus granulosa cell subpopulations obtained before $(0 \mathrm{~h})$ and $36 \mathrm{~h}$ after hCG administration. Each EP3 isoform mRNA was expressed relative to ACTB. Data are expressed as mean +S.E.M., $n=3-4$ monkeys per time point. Comparisons between subpopulations were performed using two-tailed, paired $t$-test $\left({ }^{*} P<0.05\right)$. 
Differences in the temporal or spatial expression of EP3 isoforms within the follicle may be crucial for the proper ovulatory function of granulosa cells. Granulosa cells within the ovulatory follicle can be classified into subpopulations based on their location, histological characteristics, and functions in ovulatory events. For example, cumulus granulosa cells are specialized to support the oocyte and undergo expansion to facilitate oocyte release. EP3 mRNA increased in bovine cumulus cells following the ovulatory gonadotropin surge, which plays a role in maintaining cumulus-oocyte complex quality (Calder et al. 2001). Our previous studies showed that $E P 2$ and $E P 3 \mathrm{mRNA}$ were expressed at higher levels in monkey cumulus cells than in mural cells at $36 \mathrm{~h}$ after hCG administration (Harris et al. 2011). EP2 was previously shown to respond to agonist stimulation with increased cAMP (Markosyan et al. 2006). This study extends these findings to demonstrate that EP3-9 expression is high in cumulus cells just before ovulation, and functional studies in $\mathrm{CHO}$ cells indicate that stimulation of EP3-9 also increases cAMP. Therefore, cumulus expansion in monkey may be regulated by both EP2 and EP3-9 by responding to elevated follicular PGE $_{2}$ with increased cAMP. In the mouse, Ep2 mRNA was highly expressed in cumulus cells just before ovulation (Segi et al. 2003, Takahashi et al. 2006), consistent with the concept that cumulus expansion is regulated by this Gas-coupled receptor. Mice lacking Ep2 expression have a severe deficiency in cumulus expansion, partially via reduction of tumor necrosis factor $\alpha$-induced protein 6 (Tnfaip6) selectively in cumulus cells of preovulatory follicles (Hizaki et al. 1999, Ochsner et al. 2003). Tnfaip6 contains a hyaluronan-binding LINK domain and interacts with extracellular matrix components, including hyaluronan and inter- $\alpha$ trypsin inhibitor (I $\alpha \mathrm{l})$, to stabilize the extracellular matrix during expansion of the cumulusoocyte complex (Carrette et al. 2001, Mukhopadhyay et al. 2001). In rat and human granulosa cells, $\mathrm{PGE}_{2}$ acts via the cAMP/PKA pathway to increase biosynthesis of epidermal growth factor (EGF)-like growth factors like amphiregulin and epiregulin (Ben-Ami et al. 2006, Nautiyal et al. 2010). These EGF-like growth factors participate in cumulus expansion by increasing expression of hyaluronan synthase 2 (Has2) and Tnfaip6 (Park et al. 2004). These findings support the concept that EP3-9 may cooperate with EP2, responding to $\mathrm{PGE}_{2}$ with elevated cAMP within monkey cumulus cells, to regulate key proteins involved in cumulus expansion.

$\mathrm{PGE}_{2}$-dependent events associated with follicle rupture are likely mediated in part via EP3-5. Both EP1 (Harris et al. 2011) and EP3-5 (present study) are expressed at lower levels at the follicle apex than in non-apex granulosa cells just before ovulation. Our laboratory previously showed that EP1 and EP3 increased SERPINE1, which was present at higher levels in non-apex mural granulosa cells than in apex cells (Markosyan \& Duffy 2009, Harris et al. 2011). SERPINE1 is an endogenous inhibitor of PLAT activity, a proteolytic pathway implicated in degradation of the follicle apex at ovulation (Strickland \& Beers 1976, Liu et al. 2004). High levels of SERPINE1 mediated by elevated intracellular calcium via EP1 may protect non-apex mural granulosa cells from the proteolytic action of PLAT, the primary PLAT in the monkey follicle at ovulation (Markosyan \& Duffy 2009). We have also previously shown that EP2 and EP3 increase expression of PLATin monkey granulosa cells (Markosyan \& Duffy 2009). The primary intracellular signal generated by $\mathrm{PGE}_{2}$ stimulation of these receptors in monkey granulosa cells is cAMP (Markosyan et al. 2006). However, this study shows that EP3-5 is expressed at low levels in granulosa cells at the follicle apex. As functional studies in $\mathrm{CHO}$ cells indicate that EP3-5 decreases cAMP levels, $\mathrm{PGE}_{2}$ stimulation of this EP3 receptor isoform may result in reduced $P L A T$ expression in non-apex granulosa cells, with relatively higher PLAT levels in granulosa cells at the follicle apex. Therefore, low expression of EP1 and EP3-5 at the follicle apex may result in high PLAT activity in apex mural granulosa cells and participate in defining the site of follicle rupture.

Differential expression of each EP receptor, and now each EP3 receptor isoform, in subpopulations of granulosa cells may contribute to the different roles that these subpopulations play in the process of ovulation. Functional studies in $\mathrm{CHO}$ cells indicate that monkey EP3 isoforms interact with different G-proteins to activate distinct combinations of intracellular signaling pathways. EP3 isoforms also have different temporal and spatial distributions throughout the follicle. These differences suggest that granulosa cells can generate a unique response to $\mathrm{PGE}_{2}$ dependent on gonadotropin exposure, location within the follicle, and a unique pattern of $E P$ receptor expression. Regional responses to $\mathrm{PGE}_{2}$ include patterns of gene expression that define the different ovulatory functions of granulosa cells, such as maintenance of oocyte health, expansion of the cumulus, or proteolysis at the follicle apex. By understanding the role of each EP receptor (including each EP3 isoform) in regulating ovulatory functions of granulosa cells, receptor-selective agonists and/or antagonists may be utilized to promote fertility, prevent ovulation, or create new contraceptives.

\section{Declaration of interest}

The authors declare that there is no conflict of interest that could be perceived as prejudicing the impartiality of the research reported.

\section{Funding}

This research was supported by grant funding from the Eunice Kennedy Shriver National Institute of Child Health and Human Development (HD054691) to D M Duffy. 


\section{Acknowledgements}

The authors would like to acknowledge the dedicated work of Kim Hester, Terrie Lynch, and Nicole McCann in animal training and animal handling. Recombinant human FSH and Ganirelix were generously provided by Merck \& Co. Serono Reproductive Biology Institute (Rockland, MA, USA) generously provided recombinant human $\mathrm{LH}$ and Antide.

\section{References}

An S, Yang J, So SW, Zeng L \& Goetzl EJ 1994 Isoforms of the EP3 subtype of human prostaglandin $\mathrm{E}_{2}$ receptor transduce both intracellular calcium and cAMP signals. Biochemistry 33 14496-14502. (doi:10.1021/ bi00252a016)

Ben-Ami I, Freimann S, Armon L, Dantes A, Strassburger D, Friedler S, Raziel A, Seger R, Ron-El R \& Amsterdam A $2006 \mathrm{PGE}_{2}$ up-regulates EGFlike growth factor biosynthesis in human granulosa cells: new insights into the coordination between $\mathrm{PGE}_{2}$ and $\mathrm{LH}$ in ovulation. Molecular Human Reproduction 12 593-599. (doi:10.1093/molehr/gal068)

Bilson HA, Mitchell DL \& Ashby B 2004 Human prostaglandin EP3 receptor isoforms show different agonist-induced internalization patterns. FEBS Letters 572 271-275. (doi:10.1016/j.febslet.2004.06.089)

Bogan RL, Murphy MJ, Stouffer RL \& Hennebold JD 2008a Prostaglandin synthesis, metabolism, and signaling potential in the rhesus macaque corpus luteum throughout the luteal phase of the menstrual cycle. Endocrinology 149 5861-5871. (doi:10.1210/en.2008-0500)

Bogan RL, Murphy MJ, Stouffer RL \& Hennebold JD 2008b Systematic determination of differential gene expression in the primate corpus luteum during the luteal phase of the menstrual cycle. Molecular Endocrinology 22 1260-1273. (doi:10.1210/me.2007-0484)

Bridges PJ \& Fortune JE 2007 Regulation, action and transport of prostaglandins during the periovulatory period in cattle. Molecular and Cellular Endocrinology 263 1-9. (doi:10.1016/j.mce.2006.08.002)

Calder MD, Caveney AN, Westhusin ME \& Watson AJ 2001 Cyclooxygenase-2 and prostaglandin $\mathrm{E}(2)(\mathrm{PGE}(2))$ receptor messenger RNAs are affected by bovine oocyte maturation time and cumulus-oocyte complex quality, and PGE(2) induces moderate expansion of the bovine cumulus in vitro. Biology of Reproduction 65 135-140. (doi:10.1095/ biolreprod65.1.135)

Carrette O, Nemade RV, Day AJ, Brickner A \& Larsen WJ 2001 TSG-6 is concentrated in the extracellular matrix of mouse cumulus oocyte complexes through hyaluronan and inter- $\alpha$-inhibitor binding. Biology of Reproduction 65 301-308. (doi:10.1095/biolreprod65.1.301)

Chaffin CL, Stouffer RL \& Duffy DM 1999 Gonadotropin and steroid regulation of steroid receptor and aryl hydrocarbon receptor messenger ribonucleic acid in macaque granulosa cells during the periovulatory interval. Endocrinology 140 4753-4760. (doi:10.1210/en.140.10.4753)

Coleman RA, Smith WL \& Narumiya S 1994 International Union of Pharmacology classification of prostanoid receptors: properties, distribution, and structure of the receptors and their subtypes. Pharmacological Reviews 46 205-229.

Duffy DM \& Stouffer RL 2001 The ovulatory gonadotrophin surge stimulates cyclooxygenase expression and prostaglandin production by the monkey follicle. Molecular Human Reproduction 7 731-739. (doi:10.1093/molehr/7.8.731)

Duffy DM \& Stouffer RL 2002 Follicular administration of a cyclooxygenase inhibitor can prevent oocyte release without alteration of normal luteal function in rhesus monkeys. Human Reproduction 17 2825-2831. (doi:10.1093/humrep/17.11.2825)

Duffy DM, Dozier BL \& Seachord CL 2005a Prostaglandin dehydrogenase and prostaglandin levels in periovulatory follicles: implications for control of primate ovulation by prostaglandin $E_{2}$. Journal of Clinical Endocrinology and Metabolism 90 1021-1027. (doi:10.1210/ jc.2004-1229)

Duffy DM, Seachord CL \& Dozier BL 2005b Microsomal prostaglandin E synthase-1 (mPGES-1) is the primary form of PGES expressed by the primate periovulatory follicle. Human Reproduction 20 1485-1492. (doi:10.1093/humrep/deh784)
Fleming EF, Athirakul K, Oliverio MI, Key M, Goulet J, Koller BH \& Coffman TM 1998 Urinary concentrating function in mice lacking EP3 receptors for prostaglandin $E_{2}$. American Journal of Physiology 275 F955-F961.

Garmory HS, Brown KA \& Titball RW 2003 DNA vaccines: improving expression of antigens. Genetic Vaccines and Therapy 1 2. (doi:10.1186/ 1479-0556-1-2)

Harris SM, Aschenbach LC, Skinner SM, Dozier BL \& Duffy DM 2011 Prostaglandin $E_{2}$ receptors are differentially expressed in subpopulations of granulosa cells from primate periovulatory follicles. Biology of Reproduction 85 916-923. (doi:10.1095/biolreprod.111.091306)

Hasegawa $H$, Katoh $H$, Yamaguchi $Y$, Nakamura K, Futakawa $S$ \& Negishi M 2000 Different membrane targeting of prostaglandin EP3 receptor isoforms dependent on their carboxy-terminal tail structures. FEBS Letters 473 76-80. (doi:10.1016/S0014-5793(00)01508-8)

Hizaki H, Segi E, Sugimoto $Y$, Hirose M, Saji T, Ushikubi F, Matsuoka T, Noda Y, Tanaka T, Yoshida N et al. 1999 Abortive expansion of the cumulus and impaired fertility in mice lacking the prostaglandin $\mathrm{E}$ receptor subtype EP(2). PNAS 96 10501-10506. (doi:10.1073/pnas.96. 18.10501)

Irie A, Sugimoto $Y$, Namba T, Harazono A, Honda A, Watabe A, Negishi $M$, Narumiya S \& Ichikawa A 1993 Third isoform of the prostaglandin-Ereceptor EP3 subtype with different C-terminal tail coupling to both stimulation and inhibition of adenylate cyclase. European Journal of Biochemistry 217 313-318. (doi:10.1111/j.1432-1033.1993.tb18248.x)

Irie A, Sequi E, Sugimoto Y, Ichikawa A \& Negishi M 1994 Mouse prostaglandin E receptor EP3 subtype mediates calcium signals via $\mathrm{Gi}$ in cDNA-transfected Chinese hamster ovary cells. Biochemical and Biophysical Research Communications 204 303-309. (doi:10.1006/ bbrc.1994.2460)

Israel DD \& Regan JW 2009 EP(3) prostanoid receptor isoforms utilize distinct mechanisms to regulate ERK $1 / 2$ activation. Biochimica et Biophysica Acta 1791 238-245. (doi:10.1016/j.bbalip.2009.01.021)

Jakubík J, El-Fakahany EE \& Dolezal V 2006 Differences in kinetics of xanomeline binding and selectivity of activation of $G$ proteins at $M(1)$ and M(2) muscarinic acetylcholine receptors. Molecular Pharmacology 70 656-666. (doi:10.1124/mol.106.023762)

Janíčková H, Rudajev V, Zimčík P, Jakubík J, Tanila H, El-Fakahany EE \& Doležal V 2013 Uncoupling of M1 muscarinic receptor/G-protein interaction by amyloid $\beta(1-42)$. Neuropharmacology 67 272-283. (doi:10.1016/j.neuropharm.2012.11.014)

Jin J, Mao GF \& Ashby B 1997 Constitutive activity of human prostaglandin E receptor EP3 isoforms. British Journal of Pharmacology 121 317-323. (doi:10.1038/sj.bjp.0701121)

Kotani M, Tanaka I, Ogawa Y, Usui T, Mori K, Ichikawa A, Narumiya S, Yoshimi T \& Nakao K 1995 Molecular cloning and expression of multiple isoforms of human prostaglandin E receptor EP3 subtype generated by alternative messenger RNA splicing: multiple second messenger systems and tissue-specific distributions. Molecular Pharmacology 48 869-879.

Li Q, Pangas SA, Jorgez CJ, Graff JM, Weinstein M \& Matzuk MM 2008 Redundant roles of SMAD2 and SMAD3 in ovarian granulosa cells in vivo. Molecular and Cellular Biology 28 7001-7011. (doi:10.1128/ MCB.00732-08)

Liu J, Carrière PD, Doré M \& Sirois J 1997 Prostaglandin G/H synthase-2 is expressed in bovine preovulatory follicles after the endogenous surge of luteinizing hormone. Biology of Reproduction $\mathbf{5 7}$ 1524-1531. (doi:10.1095/biolreprod57.6.1524)

Liu YX, Liu K, Feng Q, Hu ZY, Liu HZ, Fu GQ, Li YC, Zou RJ \& Ny T 2004 Tissue-type plasminogen activator and its inhibitor plasminogen activator inhibitor type 1 are coordinately expressed during ovulation in the rhesus monkey. Endocrinology 145 1767-1775. (doi:10.1210/en.2003-1327)

Markosyan N \& Duffy DM 2009 Prostaglandin $E_{2}$ acts via multiple receptors to regulate plasminogen-dependent proteolysis in the primate periovulatory follicle. Endocrinology $\mathbf{1 5 0}$ 435-444. (doi:10.1210/ en.2008-0591)

Markosyan N, Dozier BL, Lattanzio FA \& Duffy DM 2006 Primate granulosa cell response via prostaglandin $\mathrm{E}_{2}$ receptors increases late in the periovulatory interval. Biology of Reproduction 75 868-876. (doi:10.1095/biolreprod.106.053769)

Mukhopadhyay D, Hascall VC, Day AJ, Salustri A \& Fülöp C 2001 Two distinct populations of tumor necrosis factor-stimulated gene- 6 protein in 
the extracellular matrix of expanded mouse cumulus cell-oocyte complexes. Archives of Biochemistry and Biophysics 394 173-181. (doi:10.1006/abbi.2001.2552)

Murdoch WJ, Hansen TR \& McPherson LA 1993 A review - role of eicosanoids in vertebrate ovulation. Prostaglandins 46 85-115. (doi:10.1016/ 0090-6980(93)90037-8)

Narumiya S, Sugimoto Y \& Ushikubi F 1999 Prostanoid receptors: structures, properties, and functions. Physiological Reviews 79 1193-1226.

Nautiyal J, Steel JH, Rosell MM, Nikolopoulou E, Lee K, Demayo FJ, White R, Richards JS \& Parker MG 2010 The nuclear receptor cofactor receptor-interacting protein 140 is a positive regulator of amphiregulin expression and cumulus cell-oocyte complex expansion in the mouse ovary. Endocrinology 151 2923-2932. (doi:10.1210/en.2010-0081)

Ochsner SA, Russell DL, Day AJ, Breyer RM \& Richards JS 2003 Decreased expression of tumor necrosis factor- $\alpha$-stimulated gene 6 in cumulus cells of the cyclooxygenase-2 and EP2 null mice. Endocrinology 144 1008-1019. (doi:10.1210/en.2002-220435)

Park JY, Su YQ, Ariga M, Law E, Jin SL \& Conti M 2004 EGF-like growth factors as mediators of $\mathbf{L H}$ action in the ovulatory follicle. Science $\mathbf{3 0 3}$ 682-684. (doi:10.1126/science.1092463)

Peters MW, Pursley JR \& Smith GW 2004 Inhibition of intrafollicular $\mathrm{PGE}_{2}$ synthesis and ovulation following ultrasound-mediated intrafollicular injection of the selective cyclooxygenase-2 inhibitor NS-398 in cattle. Journal of Animal Science 82 1656-1662.

Schmid A, Thierauch KH, Schleuning WD \& Dinter H 1995 Splice variants of the human EP3 receptor for prostaglandin $E_{2}$. European Journal of Biochemistry 228 23-30. (doi:10.1111/j.1432-1033.1995.tb20223.x)

Segi E, Haraguchi K, Sugimoto Y, Tsuji M, Tsunekawa H, Tamba S, Tsuboi K, Tanaka S \& Ichikawa A 2003 Expression of messenger RNA for prostaglandin E receptor subtypes EP4/EP2 and cyclooxygenase isozymes in mouse periovulatory follicles and oviducts during superovulation. Biology of Reproduction 68 804-811. (doi:10.1095/biolreprod.102.003590)

Sirois J \& Doré M 1997 The late induction of prostaglandin G/H synthase-2 in equine preovulatory follicles supports its role as a determinant of the ovulatory process. Endocrinology 138 4427-4434. (doi:10.1210/en.138. 10.4427)

Strickland S \& Beers WH 1976 Studies on the role of plasminogen activator in ovulation. In vitro response of granulosa cells to gonadotropins, cyclic nucleotides, and prostaglandins. Journal of Biological Chemistry 251 5694-5702.

Sugimoto $Y$, Negishi M, Hayashi $Y$, Namba T, Honda A, Watabe A, Hirata M, Narumiya S \& Ichikawa A 1993 Two isoforms of the EP3 receptor with different carboxyl-terminal domains. Identical ligand binding properties and different coupling properties with Gi proteins. Journal of Biological Chemistry 286 2712-2718.

Takahashi T, Morrow JD, Wang H \& Dey SK 2006 Cyclooxygenase2-derived prostaglandin $\mathrm{E}(2)$ directs oocyte maturation by differentially influencing multiple signaling pathways. Journal of Biological Chemistry 281 37117-37129. (doi:10.1074/jbc.M608202200)
Talasila A, Germack R \& Dickenson IM 2009 Characterization of P2Y receptor subtypes functionally expressed on neonatal rat cardiac myofibroblasts. British Journal of Pharmacology 158 339-353. (doi:10.1111/j.1476-5381.2009.00172.x)

Tamma G, Wiesner B, Furkert J, Hahm D, Oksche A, Schaefer M, Valenti G, Rosenthal W \& Klussmann E 2003 The prostaglandin $E_{2}$ analogue sulprostone antagonizes vasopressin-induced antidiuresis through activation of Rho. Journal of Cell Science 116 3285-3294. (doi:10.1242/jcs.00640)

Thiruppathi P, Shatavi S, Dias JA, Radwanska E \& Luborsky JL 2001 Gonadotrophin receptor expression on human granulosa cells of low and normal responders to FSH. Molecular Human Reproduction 7 697-704. (doi:10.1093/molehr/7.8.697)

Tomić M, Van Goor F, He M-L, Zivadinovic D \& Stojilkovic SS 2002 $\mathrm{Ca}(2+)$-mobilizing endothelin-A receptors inhibit voltage-gated $\mathrm{Ca}(2+)$ influx through $\mathrm{G}(\mathrm{i} / \mathrm{o})$ signaling pathway in pituitary lactotrophs. Molecular Pharmacology 61 1329-1339. (doi:10.1124/mol.61.6.1329)

Tsafriri A, Lindner HR, Zor U \& Lamprecht SA 1972 Physiological role of prostaglandins in the induction of ovulation. Prostaglandins 2 1-10. (doi:10.1016/0090-6980(72)90024-X)

Tsai SJ, Wiltbank MC \& Bodensteiner KJ 1996 Distinct mechanisms regulate induction of messenger ribonucleic acid for prostaglandin (PG) $\mathrm{G} / \mathrm{H}$ synthase-2, PGE (EP3) receptor, and PGF2 $\alpha$ receptor in bovine preovulatory follicles. Endocrinology 137 3348-3355. (doi:10.1210/en. 137.8.3348)

Vandevoort CA, Baughman WL \& Stouffer RL 1989 Comparison of different regimens of human gonadotropins for superovulation of rhesus monkeys: ovulatory response and subsequent luteal function. Journal of In Vitro Fertilization and Embryo Transfer 6 85-91. (doi:10.1007/BF01130732)

Weick RF, Dierschke DJ, Karsch FJ, Butler WR, Hotchkiss J \& Knobil E 1973 Periovulatory time courses of circulating gonadotropic and ovarian hormones in the rhesus monkey. Endocrinology 93 1140-1147. (doi:10.1210/endo-93-5-1140)

Wong WY \& Richards JS 1991 Evidence for two antigenically distinct molecular weight variants of prostaglandin $\mathrm{H}$ synthase in the rat ovary. Molecular Endocrinology 5 1269-1279. (doi:10.1210/mend-59-1269)

Xing Y, Gosden R, Lasko P \& Clarke H 2006 Murine homologues of the Drosophila gustavus gene are expressed in ovarian granulosa cells. Reproduction 131 905-915. (doi:10.1530/rep.1.01046)

Yang J, Xia M, Goetzl EJ \& An S 1994 Cloning and expression of the EP3subtype of human receptors for prostaglandin $\mathrm{E}_{2}$. Biochemical and Biophysical Research Communications 198 999-1006. (doi:10.1006/ bbrc.1994.1142)

Received 27 June 2013

First decision 15 July 2013

Revised manuscript received 19 September 2013

Accepted 23 September 2013 